\title{
Phenotypic and Genotypic Characterization of ESBL-, AmpC-, and Carbapenemase-Producing Klebsiella pneumoniae and Escherichia coli Isolates
}

\author{
Hossein Kazemian ${ }^{\text {a, b }}$ Hamid Heidaric Roya Ghanavatid Sobhan Ghafourian ${ }^{\text {a }}$ \\ Fateme Yazdani $^{\mathrm{e}}$ Nourkhoda Sadeghifard $^{\mathrm{a}}$ Hasan Valadbeigi ${ }^{\mathrm{a}}$ Abbas Maleki $^{\mathrm{a}}$ \\ Iraj Pakzad ${ }^{a}$ \\ ${ }^{a}$ Clinical Microbiology Research Center, Ilam University of Medical Sciences, llam, Iran; \\ ${ }^{b}$ Department of Microbiology, School of Medicine, Tehran University of Medical Sciences, Tehran, Iran; \\ 'Department of Microbiology, Faculty of Medicine, Shahid Sadoughi University of Medical Sciences, Yazd, Iran; \\ ${ }^{\mathrm{d}}$ Department of Microbiology, School of Medicine, Iran University of Medical Sciences, Tehran, Iran; \\ e Molecular Microbiology Research Center, Faculty of Medicine, Shahed University, Tehran, Iran
}

\section{Significance of the Study}

- Given the importance of drug-resistant Klebsiella pneumoniae and Escherichia coli strains in hospitalacquired infections, the aim of this study was to determine the characteristics of ESBL, AmpC, and carbapenemase-producing isolates. Coexistence of AmpC, ESBL, and carbapenemase genes was observed in some isolates. Implementing up-to-date strategies against such organisms is warranted.

\section{Keywords}

Klebsiella pneumoniae - Escherichia coli $\cdot$ ESBLs $\cdot$ AmpC .

Carbapenemase

\begin{abstract}
Objectives: Drug resistance among gram-negative bacteria is a worldwide challenge. Due to the importance of drugresistant Klebsiella pneumoniae and Escherichia coli strains in hospital-acquired infections, we aimed to determine the phenotypic and genotypic characteristics of ESBL-, AmpC-, and carbapenemase-producing isolates obtained from hospitalized patients in Tehran and Ilam (Iran). Materials and
\end{abstract}

\begin{tabular}{ll}
\hline KARGER & $\begin{array}{l}\text { (c) } 2019 \text { The Author(s) } \\
\text { Published by S. Karger AG, Basel }\end{array}$ \\
E-Mail karger@karger.com & $\begin{array}{l}\text { This is an Open Access article licensed under the Creative Commons } \\
\text { Attribution-NonCommercial-4.0 International License (CC BY-NC) } \\
\text { (http://www.karger.com/Services/OpenAccessicense), applicable to } \\
\text { the online version of the article only. Usage and distribution for com- } \\
\text { mercial purposes requires written permission. }\end{array}$
\end{tabular}

Methods: In total, $90 \mathrm{~K}$. pneumoniae isolates and $65 \mathrm{E}$. coli isolates were collected from various infections. Phenotypic identification of bacterial isolates was performed using standard methods. Phenotypic screening of ESBL, AmpC, and carbapenemase enzymes was carried out. Detection of ESBL, $\mathrm{AmpC}$, and carbapenemase genes was also performed by the PCR method. Results: Phenotypic detection tests showed that $36(40 \%)$ K. pneumoniae and 23 (35.4\%) E. coli isolates were ESBL producers. Moreover, 18 (20\%) and 6 (9.2\%) K. pneumoniae and $E$. coli isolates were AmpC producers, respectively. Modified Hodge test results indicated that 39

H.K. and H.H. contributed equally to this work as first authors. 
(43.3\%) K. pneumoniae and 18 (27.7\%) E. coli isolates produced carbapenemase. Molecular tests showed that $40 \%$ of K. pneumoniae and $36.9 \%$ of $E$. coli isolates were ESBL positive. AmpC was detected in 24.4 and $13.8 \%$ of K. pneumoniae and E. coli isolates. Carbapenemase was detected in 34 (37.8\%) K. pneumoniae and $13(20 \%)$ E. coli isolates. Conclusion: In this study, 3 K. pneumoniae isolates simultaneously carried ESBL, AmpC, and carbapenemase genes. Upto-date strategies such as combination therapy or utilization of new antimicrobial agents might help to combat such drug-resistant organisms.

(C) 2019 The Author(s)

Published by S. Karger AG, Basel

\section{Introduction}

Drug resistance in gram-negative bacteria is a worldwide challenge [1]. Major resistance to gram-negative pathogens is related to Enterobacteriaceae, Acinetobacter baumannii, and Pseudomonas aeruginosa [2]. In the Enterobacteriaceae family, Klebsiella pneumoniae and Escherichia coli have notable drug resistance. Also, they are the common cause of hospital- and community-acquired infections $[3,4]$.

The wide distribution of extended-spectrum $\beta$-lactamases (ESBLs) amongst Enterobacteriaceae has been attributed to the over- or misuse of these antibiotics [5]. ESBLs are able to hydrolyze various types of $\beta$-lactam antibiotics, including cephalosporins and monobactams. Therefore, treating infections caused by ESBL-producing bacteria has become a complicated issue [5, 6]. Dissemination of hospital-acquired infections can be prevented via early detection of infections caused by such microorganisms [7].

Carbapenems have been considered as the treatment of choice for ESBL-producing gram-negative bacterial infections. Carbapenemase-producing strains cause serious infections in hospitalized patients and are associated with mortality [8]; hence, the use of molecular techniques could be helpful in accurately diagnosing infections caused by ESBL- and carbapenemase-producing organisms.

Drug-resistant strains of K. pneumoniae and E. coli in hospital-acquired infections are important [9]; thus, the aim of the present study was to determine the phenotypic and genotypic characterization of ESBL-, AmpC-, and carbapenemase-producing isolates of $K$. pneumoniae and E. coli obtained from hospital-associated infections in Tehran and Ilam (Iran).

\section{Materials and Methods}

\section{Bacterial Strains}

A total of $90 \mathrm{~K}$. pneumoniae and $65 \mathrm{E}$. coli isolates were obtained from various infections of hospitalized patients between April 2016 and March 2017 in Tehran and Ilam. Phenotypic and biochemical identification of bacterial isolates was performed according to standard methods [10].

\section{Phenotypic Screening of ESBL, AmpC, and Carbapenemase} Enzymes

All isolates were initially screened for ESBL production by a combined disk method according to the guidelines of the Clinical Laboratory Standards Institute (CLSI) [11]. Briefly, susceptibility to cefotaxime $(30 \mu \mathrm{g})$, cefotaxime/clavulanate $(30 / 10 \mu \mathrm{g})$, ceftazidime $(30 \mu \mathrm{g})$, and ceftazidime/clavulanate $(30 / 10 \mu \mathrm{g})$ (Mast Co., UK) was determined on Müller-Hinton agar (Merck Co, Germany). ESBL-producing strains were recognized by an at least 5-mm increase in zone diameter around cefotaxime/clavulanate and ceftazidime/clavulanate disks in comparison with disks without clavulanic acid. E. coli ATCC 35218 was used as the control strain [11].

Cefoxitin disks $(30 \mu \mathrm{g})$ were used to screen AmpC-producing isolates according to CLSI recommendations [11]. A cefoxitincloxacillin double-disk synergy test was carried out to confirm AmpC production, as previously described [12].

The modified Hodge test (MHT) was performed to screen carbapenemase-producing isolates [11]. K. pneumoniae ATCC BAA1705 and BAA-1706 were used as MHT-positive and -negative controls [11].

\section{Detection of ESBL-, AmpC-, and Carbapenemase-Related}

Genes

Polymerase chain reaction was performed using specific primers to detect genes encoding ESBLs $\left(b l a_{\mathrm{TEM}}, b l a_{\mathrm{SHV}}, b l a_{\mathrm{CTX}-\mathrm{M}}\right.$, and $\left.b l a_{\mathrm{PER}}\right), \operatorname{AmpC}\left(b l a_{\mathrm{ACC}}, b l a_{\mathrm{DHA}}, b l a_{\mathrm{EBC}}, b l a_{\mathrm{FOX}}, b l a_{\mathrm{MOX}}\right.$, and $\left.b l a_{\mathrm{CIT}}\right)$, and carbapenemase $\left(b l a_{\mathrm{IMP}}, b l a_{\mathrm{VIM}}, b l a_{\mathrm{NDM}}, b l a_{\mathrm{KPC}}\right.$, and $\left.b l a_{\text {OXA-48-like }}\right)$, as previously described [13-17]. The products were separated by electrophoresis in $1 \%$ agarose gel with $1 \times$ TBE (Tris/ borate/EDTA) buffer, stained with safe stain load dye (CinnaGen Co., Tehran, Iran) and visualized under ultraviolet illumination.

\section{Statistical Analysis}

The distribution of resistance genes among resistant and susceptible isolates was calculated using $\chi^{2}$ and Fisher's exact tests for each gene. $p$ values $\leq 0.05$ were considered to be statistically significant.

\section{Results}

Phenotypic ESBL detection tests indicated that 36 (40\%) K. pneumoniae isolates and $23(35.4 \%)$ E. coli isolates were ESBL producers. Moreover, 32 (35.5\%) K. pneumoniae and 19 (29.2\%) E. coli isolates were AmpC positive, while phenotypic confirmatory tests showed that $18(20 \%)$ and $6(9.2 \%)$ K. pneumoniae and E. coli strains, respectively, were AmpC producers; 39 (43.3\%) 
Table 1. Distribution of ESBL-associated genes among K. pneumoniae and E. coli isolates

\begin{tabular}{|c|c|c|c|c|c|c|}
\hline \multirow[t]{2}{*}{ Isolate } & \multicolumn{2}{|l|}{ ESBL } & \multirow[t]{2}{*}{$b l a_{\mathrm{TEM}}$} & \multirow[t]{2}{*}{$b l a_{\mathrm{SHV}}$} & \multirow[t]{2}{*}{$b l a_{\text {СтХ-М }}$} & \multirow[t]{2}{*}{$b l a_{\mathrm{PER}}$} \\
\hline & phenotypic & genotypic & & & & \\
\hline K. pneumoniae & $36(40)$ & $36(40)$ & $21(23.3)^{*}$ & $19(21.1)^{*}$ & $10(11.1)$ & 0 \\
\hline E. coli & $23(35.4)$ & $24(36.9)$ & $11(16.9)$ & $11(16.9)$ & $14(21.5)^{*}$ & 0 \\
\hline
\end{tabular}

Values are presented as $n(\%){ }^{*} p<0.05$

Table 2. Distribution of AmpC-related genes among K. pneumoniae and E. coli isolates

\begin{tabular}{|c|c|c|c|c|c|c|c|c|c|}
\hline \multirow[t]{2}{*}{ Isolate } & \multicolumn{3}{|l|}{ AmpC positive } & \multirow[t]{2}{*}{$b l a_{\mathrm{ACC}}$} & \multirow[t]{2}{*}{$b l a_{\mathrm{DHA}}$} & \multirow[t]{2}{*}{$b l a_{\mathrm{EBC}}$} & \multirow[t]{2}{*}{$b l a_{\mathrm{FOX}}$} & \multirow[t]{2}{*}{$b l a_{\mathrm{MOX}}$} & \multirow[t]{2}{*}{$b l a_{\mathrm{CIT}}$} \\
\hline & screening test & confirmatory test & genotypic & & & & & & \\
\hline K. pneumoniae & $32(35.5)$ & $18(20)$ & $22(24.4)$ & 0 & $15(16.6)^{*}$ & $12(13.3)$ & 0 & 0 & $5(5.5)$ \\
\hline E. coli & $19(29.2)$ & $6(9.2)$ & $9(13.8)$ & 0 & $4(6.1)$ & $3(4.6)$ & 0 & 0 & $2(3)$ \\
\hline
\end{tabular}

Values are presented as $\mathrm{n}(\%) .{ }^{*} \mathrm{p}<0.05$

Table 3. Carbapenem resistance patterns among K. pneumoniae and E. coli isolates

\begin{tabular}{|c|c|c|c|c|c|c|c|}
\hline \multirow[t]{2}{*}{ Isolate } & \multicolumn{2}{|c|}{ Carbapenemase producer } & \multirow[t]{2}{*}{$b l a_{\mathrm{IMP}}$} & \multirow[t]{2}{*}{$b l a_{\mathrm{VIM}}$} & \multirow[t]{2}{*}{$b l a_{\mathrm{NDM}}$} & \multirow[t]{2}{*}{$b l a_{\mathrm{KPC}}$} & \multirow[t]{2}{*}{$b l a_{\mathrm{OXA}-48-\text { like }}$} \\
\hline & MHT & genotypic & & & & & \\
\hline K. pneumoniae & $39(43.3)$ & $34(37.8)$ & $1(1.1)$ & $30(33.3)^{*}$ & 0 & 0 & $13(14.4)$ \\
\hline E. coli & $18(27.7)$ & $13(20)$ & 0 & $8(12.3)$ & 0 & 0 & $13(20)^{*}$ \\
\hline
\end{tabular}

Values are presented as $n(\%)$. MHT, modified Hodge test. ${ }^{*} p<0.05$.

K. pneumoniae and 18 (27.7\%) E. coli strains produced carbapenemase.

Molecular methods showed that $36(40 \%) \mathrm{K}$. pneumoniae isolates harbored at least 1 of the ESBL-related genes. Distribution of these genes among $K$. pneumoniae strains were $b l a_{\mathrm{TEM}} 23.3 \%, b l a_{\mathrm{SHV}} 21.1 \%$, and $b l a_{\mathrm{CTX}-\mathrm{M}}$ $11.1 \%$. Presence of $b l a_{\mathrm{TEM}}$ and $b l a_{\mathrm{SHV}}$ genes in ESBL-producing $K$. pneumoniae isolates was statistically significant $(p<0.05)$. In addition, $24(36.9 \%) E$. coli isolates were ESBL positive. The prevalence of $b l a_{\mathrm{TEM}}$ and $b l a_{\mathrm{SHV}}$ genes was $16.9 \%$, and $b l a_{\text {CTX-M }}$ was observed in $21.5 \%$ of isolates. The $b l a_{\text {PER }}$ gene was not detected in any of the

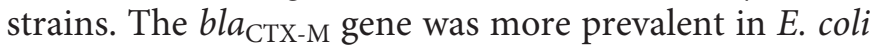
isolates which were ESBL producers (Table 1).

AmpC-associated genes were detected amongst 22 (24.4\%) K. pneumoniae isolates. bla $a_{\mathrm{DHA}}, b l a_{\mathrm{CIT}}$, and $b l a_{\mathrm{EBC}}$ were found among $16.6,5.5$, and $13.3 \%$ of $K$. pneumoniae strains, respectively. $b l a_{\text {DHA }}$ prevalence in AmpC-posi- tive $K$. pneumoniae isolates was statistically significant $(p<0.05)$. Furthermore, $9(13.8 \%)$ of the $E$. coli isolates carried AmpC genes, and the distribution percentages of $b l a_{\mathrm{DHA}}, b l a_{\mathrm{CIT}}$, and $b l a_{\mathrm{EBC}}$ were $6.1,3$, and $4.6 \%$, respectively. All the strains were negative for $b l a_{\mathrm{ACC}}, b l a_{\mathrm{FOX}}$, and $b l a_{\text {MOX }}$ (Table 2).

Carbapenemase-related genes were detected in 34 (37.8\%) K. pneumoniae isolates. The prevalence rates of these genes were $b l a_{\mathrm{VIM}} 33.3 \%$, $b l a_{\mathrm{OXA}-48-\text { like }} 14.4 \%$, and $b l a_{\mathrm{IMP}} 1.1 \%$. Thirteen (20\%) E. coli isolates were carbapenemase positive. $b l a_{\mathrm{VIM}}$ and $b l a_{\mathrm{OXA}-48 \text {-like }}$ were observed in 12.3 and $20 \%$ of isolates, respectively. No $b l a_{\mathrm{IMP}}$ gene was detected in E. coli strains. bla $a_{\mathrm{NDM}}$ and $b l a_{\mathrm{KPC}}$ genes were not found in any of the bacterial isolates. bla $a_{\mathrm{VIM}}$ and $b l a_{\text {OXA-48-like }}$ gene distribution was significantly different $(p<0.05)$ among $K$. pneumoniae and E. coli isolates (Table 3). 


\section{Discussion}

In the present study, the prevalence of ESBL-, AmpC-, and carbapenemase-associated genes were investigated by phenotypic and genotypic methods in clinical isolates of K. pneumoniae and E. coli. According to the phenotypic results, the prevalence of ESBL-producing K. pneumoniae and E. coli was notable. The genotypic method confirmed the phenotypic method results, except for $1 E$. coli strain. Although this isolate harbored 1 ESBL-related gene, it did not show phenotypic resistance. Similarly, unexpressed ESBL genes in antibiotic-susceptible isolates were previously reported [18]. Horizontal gene transfer to other bacteria is possible via such strains [18].

Notable frequencies of ESBL-producing K. pneumoniae and E. coli strains were reported in Iran $[19,20]$. It seems that the prevalence of ESBL-producing gram-negative bacteria is increasing in the country [20].

In the present study, $8 \mathrm{~K}$. pneumoniae isolates carried 2 ESBL genes, and 3 isolates harbored 3 ESBL genes simultaneously. Moreover, the simultaneous presence of 2 and 3 ESBL genes was observed in 6 and 3 strains of $E$. coli, respectively. The copresence of ESBL genes among clinical E. coli isolates was previously stated [21].

In the present study, AmpC screening and confirmatory phenotypic tests produced different results. Similar to a previous study, a high rate of false-negative results was reported by phenotypic detection methods for AmpC [13]. In our study, AmpC-producing $K$. pneumoniae strains were higher than in a previous report from Iran [22]. However, a notable frequency of AmpC-producing K. pneumoniae isolates (43\%) was reported among burnt patients [13]. Dissemination of AmpC $\beta$-lactamases between near half of clinical gramnegative bacilli has been reported $[13,23,24]$. In the present study, $6 \mathrm{AmpC}$-producing K. pneumoniae isolates carried $b l a_{\mathrm{DHA}}$ and $b l a_{\mathrm{EBC}}$ simultaneously, and copresence of $b l a_{\mathrm{DHA}}, b l a_{\mathrm{EBC}}$, and $b l a_{\mathrm{CIT}}$ was observed in 2 isolates. Recently, the coexistence of AmpC $\beta$-lactamase genes in $K$. pneumoniae was reported for the first time [13]. To eradicate AmpC-producing bacteria, carbapenems can be used as primary agents, but AmpC $\beta$-lactamases might increase the MIC values of carbapenems and confer resistance to the carbapenem family $[13,25]$.

A frequent gene among carbapenemase-producing $K$. pneumoniae was bla $a_{V I M}$, but only 1 harbored the bla $a_{\mathrm{IMP}}$ gene. Similarly, in a previous study, the bla $a_{\mathrm{VIM}}$ gene was more frequent than the $b l a_{\mathrm{IMP}}$ gene [26]. The $b l a_{\mathrm{KPC}}$ and $b l a_{\text {NDM }}$ genes were not detected in any of the investigated strains, while the presence of bla $a_{\mathrm{KPC}}$ was notable in $K$. pneumoniae isolates in Iran [27]. Also, in a study by Hosseinzadeh et al. [28], $>10 \%$ of the isolates carried the $b l a_{\mathrm{NDM}-1}$ gene.

Among carbapenemase-producing K. pneumoniae, $8(23.5 \%)$ isolates simultaneously harbored $b l a_{\mathrm{VIM}}$ and $b l a_{\mathrm{OXA}-48-\mathrm{like}}$ genes, and the copresence of bla $a_{\mathrm{VIM}}$, $b l a_{\text {OXA-48-like, and }} b l a_{\text {IMP }}$ genes was detected in only 1 isolate (2.9\%). Among carbapenemase-producing E. coli isolates, $8(61.5 \%)$ carried $b l a_{\mathrm{VIM}}$ and $b l a_{\mathrm{OXA}-48 \text {-like }}$ genes simultaneously. The bla $a_{\text {OXA-48-like gene was detected }}$ among all of them.

Our results indicated that some resistance genes were present amongst the resistant strains, which was statistically significant $(p<0.05)$. These appear to be the most frequent ESBL-, AmpC-, and carbapenemase-related genes in our region (Tables 1-3). Coexistence of ESBL, AmpC, and metallo- $\beta$-lactamases was reported amongst A. baumannii strains in 2013 [29]. Pokhrel et al. [30] showed the copresence of ESBLs and carbapenemase in clinical E. coli isolates in Nepal.

The current study shows that $2 \mathrm{~K}$. pneumoniae isolates simultaneously carried 2 ESBL ( $b l a_{\mathrm{CTX}-\mathrm{M}}, b l a_{\mathrm{TEM}} / b l a_{\mathrm{CTX}-\mathrm{M}}$, $\left.b l a_{S H V}\right), 2 \mathrm{AmpC}\left(b l a_{\mathrm{DHA}}\right.$ and $\left.b l a_{\mathrm{EBC}}\right)$, and 2 carbapenemase genes $\left(b l a_{\mathrm{VIM}}\right.$ and $\left.b l a_{\mathrm{OXA}-48-\text { like }}\right)$. Moreover, coexistence of $3 \mathrm{ESBL}$ ( $b l a_{\mathrm{CTX}-\mathrm{M}}, b l a_{\mathrm{TEM}}$, and $\left.b l a_{\mathrm{SHV}}\right), 1 \mathrm{AmpC}$ $\left(b l a_{\mathrm{DHA}}\right)$, and 3 carbapenemase genes $\left(b l_{\mathrm{VIM}}, b l a_{\mathrm{OXA}-48 \text {-like, }}\right.$ and $\left.b l a_{\mathrm{IMP}}\right)$ was seen in 1 of the studied isolates.

\section{Conclusion}

For the first time, we reported the occurrences of ESBL, AmpC, and carbapenemase genes in K. pneumoniae strains in Iran. In the present study, 2 isolates simultaneously carried 2 ESBL genes, 2 AmpC, and 2 carbapenemase genes. Moreover, coexistence of $3 \mathrm{ESBL}, 1$ AmpC, and 3 carbapenemase genes was observed in $1 \mathrm{~K}$. pneumoniae isolate. Therefore, K. pneumoniae can be considered as a major pathogen and important hazard for public health. Up-to-date treatment with combination therapy and/or new antimicrobial agents, for example, might be helpful against such drug-resistant organisms.

\section{Acknowledgment}

This study was supported by the Ilam University of Medical Sciences (project No. 959017/144). 


\section{Statement of Ethics}

This study was approved by the Ethics Committee of Ilam University of Medical Sciences.

\section{Disclosure Statement}

The authors declare that there is no conflict of interest.

\section{References}

1 Frieri M, Kumar K, Boutin A. Antibiotic resistance. J Infect Public Health. 2017 Jul - Aug; 10(4):369-78

2 Rossolini GM, Mantengoli E. Antimicrobial resistance in Europe and its potential impact on empirical therapy. Clin Microbiol Infect. 2008 Dec;14 Suppl 6:2-8.

3 Iredell J, Brown J, Tagg K. Antibiotic resistance in Enterobacteriaceae: mechanisms and clinical implications. BMJ. 2016 Feb;352:h6420.

4 Paczosa MK, Mecsas J. Klebsiella pneumoniae: going on the offense with a strong defense. Microbiol Mol Biol Rev. 2016 Jun; 80(3):629-61.

5 Peirano G, Sang JH, Pitondo-Silva A, Laupland KB, Pitout JD. Molecular epidemiology of extended-spectrum- $\beta$-lactamase-producing Klebsiella pneumoniae over a 10 year period in Calgary, Canada. J Antimicrob Chemother. 2012 May;67(5):1114-20.

6 Ma Y, Bao C, Liu J, Hao X, Cao J, Ye L, et al. Microbiological characterisation of Klebsiella pneumoniae isolates causing bloodstream infections from five tertiary hospitals in Beijing, China. J Glob Antimicrob Resist. 2018 Mar; 12:162-6.

7 Nakai H, Hagihara M, Kato H, Hirai J, Nishiyama N, Koizumi Y, et al. Prevalence and risk factors of infections caused by extended-spectrum $\beta$-lactamase (ESBL)-producing Enterobacteriaceae. J Infect Chemother. 2016 May; 22(5):319-26.

8 Jayol A, Nordmann P, Brink A, Villegas MV, Dubois V, Poirel L. High-Level Resistance to Colistin Mediated by Various Mutations in the crrB Gene among Carbapenemase-Producing Klebsiella pneumoniae. Antimicrob Agents Chemother. 2017 Oct;61(11):e01423-17.

9 Mosqueda-Gómez JL, Montaño-Loza A, Rolón AL, Cervantes C, Bobadilla-del-Valle JM, SilvaSánchez J, et al. Molecular epidemiology and risk factors of bloodstream infections caused by extended-spectrum $\quad \beta$-lactamase-producing Klebsiella pneumoniae A case-control study. Int J Infect Dis. 2008 Nov;12(6):653-9.

10 Mahmoudi S, Mahzari M, Banar M, Pourakbari B, Haghi Ashtiani MT, Mohammadi M, et al. Antimicrobial resistance patterns of Gram-negative bacteria isolated from bloodstream infections in an Iranian referral paediatric hospital: A 5.5-year study. J Glob Antimicrob Resist. 2017 Dec;11:17-22.

11 Wayne P. CLSI. Performance standards for antimicrobial susceptibility testing; twentyfifth informational supplement. CLSI Document M100-S25. Wayne, PA: Clinical and Laboratory Standards Institute; 2015.
12 Mohd Khari FI, Karunakaran R, Rosli R, Tee Tay S. Genotypic and Phenotypic Detection of AmpC $\beta$-lactamases in Enterobacter spp. Isolated from a Teaching Hospital in Malaysia. PLoS One. 2016 Mar;11(3):e0150643.

13 Ghanavati R, Darban-Sarokhalil D, NavabMoghadam F, Kazemian H, Irajian G, Razavi S. First report of coexistence of AmpC beta-lactamase genes in Klebsiella pneumoniae strains isolated from burn patients. Acta Microbiol Immunol Hung. 2017 Dec;64(4):455-62.

14 Celenza G, Pellegrini C, Caccamo M, Segatore B, Amicosante G, Perilli M. Spread of bla (CTX-M-type) and bla(PER-2) $\beta$-lactamase genes in clinical isolates from Bolivian hospitals. J Antimicrob Chemother. 2006 May; 57(5):975-8.

15 Stürenburg E, Lang M, Horstkotte MA, Laufs R, Mack D. Evaluation of the MicroScan ESBL plus confirmation panel for detection of extended-spectrum $\beta$-lactamases in clinical isolates of oxyimino-cephalosporin-resistant Gram-negative bacteria. J Antimicrob Chemother. 2004 Nov;54(5):870-5.

16 Edelstein M, Pimkin M, Palagin I, Edelstein I, Stratchounski L. Prevalence and molecular epidemiology of CTX-M extended-spectrum $\beta$-lactamase-producing Escherichia coli and Klebsiella pneumoniae in Russian hospitals. Antimicrob Agents Chemother. 2003 Dec; 47(12):3724-32.

17 Poirel L, Walsh TR, Cuvillier V, Nordmann P. Multiplex PCR for detection of acquired carbapenemase genes. Diagn Microbiol Infect Dis. 2011 May;70(1):119-23.

18 Zhang Z, Zhai Y, Guo Y, Li D, Wang Z, Wang J, et al. Characterization of Unexpressed Extended-Spectrum Beta-Lactamase Genes in Antibiotic-Sensitive Klebsiella pneumoniae Isolates. Microb Drug Resist. 2018 Jul/Aug; 24(6):799-806.

19 Zandi H, Tabatabaei SM, Ehsani F, Zarch MB, Doosthosseini S. Frequency of ExtendedSpectrum Beta-lactamases (ESBLs) in strains of Klebsiella and E. coli isolated from patients hospitalized in Yazd. Electron Physician. 2017 Feb;9(2):3810-5.

20 Leylabadlo HE, Pourlak T, Bialvaei AZ, Aghazadeh M, Asgharzadeh M, Kafil HS. Extended-Spectrum Beta-Lactamase Producing Gram Negative Bacteria in Iran: A Review. Afr J Infect Dis. 2017 Jun;11(2):39-53.
21 Tayebi Z, Heidari H, Kazemian H, Ghafoori SM, Boroumandi S, Houri H. Comparison of quinolone and beta-lactam resistance among Escherichia coli strains isolated from urinary tract infections. Infez Med. 2016 Dec;24(4):326-30.

22 Azimi L, Erajiyan G, Talebi M, Owlia P, Bina M, Shojaie A, et al. Phenotypic and Molecular Characterization of Plasmid Mediated AmpC among Clinical Isolates of Klebsiella pneumoniae Isolated from Different Hospitals in Tehran. J Clin Diagn Res. 2015 Apr;9(4): DC01-03.

23 Doddaiah V, Anjaneya D. Prevalence of ESBL, AmpC and carbapenemase among Gram negative bacilli isolated from clinical specimens. Am J Life Sci. 2014;2(2):76-81.

24 Grover N, Sahni AK, Bhattacharya S. Therapeutic challenges of ESBLS and AmpC betalactamase producers in a tertiary care center. Med J Armed Forces India. 2013 Jan;69(1): 4-10.

25 Hsieh WS, Wang NY, Feng JA, Weng LC, Wu $\mathrm{HH}$. Identification of DHA-23, a novel plasmid-mediated and inducible AmpC beta-lactamase from Enterobacteriaceae in Northern Taiwan. Front Microbiol. 2015 May;6:436.

26 Khodadadian R, Rahdar HA, Javadi A, Safari M, Khorshidi A. Detection of VIM-1 and IMP-1 genes in Klebsiella pneumoniae and relationship with biofilm formation. Microb Pathog. 2018 Feb;115:25-30.

27 Firoozeh F, Aghaseyed-Hosseini M, Zibaei M, Piroozmand A. Detection of blaKPC and blaGES Carbapenemase Genes in Klebsiella pneumoniae Isolated from Hospitalized $\mathrm{Pa}$ tients in Kashan, Iran. Recent Pat Antiinfect Drug Discov. 2016;11(2):183-8.

28 Hosseinzadeh Z, Sedigh Ebrahim-Saraie H, Sarvari J, Mardaneh J, Dehghani B, RokniHosseini SM, et al. Emerge of blaNDM-1 and blaOXA-48-like harboring carbapenem-resistant Klebsiella pneumoniae isolates from hospitalized patients in southwestern Iran. J Chin Med Assoc. 2018 Jun;81(6):536-40.

29 Gupta V, Garg R, Garg S, Chander J, Attri AK. Coexistence of Extended Spectrum Beta-Lactamases, AmpC Beta-Lactamases and Metallo-Beta-Lactamases in Acinetobacter baumannii from burns patients: a report from a tertiary care centre of India. Ann Burns Fire Disasters. 2013 Dec;26(4):189-92.

30 Pokhrel RH, Thapa B, Kafle R, Shah PK, Tribuddharat C. Co-existence of beta-lactamases in clinical isolates of Escherichia coli from Kathmandu, Nepal. BMC Res Notes. 2014 Oct;7(1):694. 